\title{
STUDIES ON SEED GERMINATION OF SAUSAGE TREE (KIGELIA PINNATA (JACQ) D.C.)
}

\author{
Magda A. Ahmed \\ Botanical Garden Res. Dept., Hort. Res. Inst., ARC, Giza, Egypt
}

Received: May 18, 2016

Accepted: Jul. 31, 2016

ABSTRACT: The present study was conducted under the full sun at the nursery of Orman Botanic Garden, Hort. Res. Inst., Giza, Egypt during 2014 and 2015 seasons in order to reveal the response of Sausage tree (Kigelia pinnata (Jacq) D.C.) seeds to some pregermination treatments including, seeds without treatment (control), soaking in tap water for either 24 or 48 hours under room temperature, soaking in hot water $\left(60-70{ }^{\circ} \mathrm{C}\right)$ for $24 \mathrm{~h}$. and soaking in diluted sulphuric acid (50\%) for either 1 or $2 h$. which followed by soaking in tap water for only $12 h$. under room temperature in a complete randomized experiment, with 3 replicates of 10 seeds. The results of the study have shown that the maximal percent of germination was achieved in the two seasons by soaking the seeds in tap water for $48 \mathrm{~h}$ treatment which followed by soaking also in tap water, but only for $24 \mathrm{~h}$, while the least germination \% was attained in both seasons by soaking either in hot water (24 h) or in diluted $\mathrm{H}_{2} \mathrm{SO}_{4}(1$ or $2 \mathrm{~h}$.). The tap water soaking for 48 $h$ treatment was also accelerated germination rate and velocity more than the control, but hot water and diluted $\mathrm{H}_{2} \mathrm{SO}_{4}$ treatments significantly delayed them. Most of the used treatments slightly improved the mean of germination rate index with non-significant differences in between, whereas the means of vigour index, seed viability, hypocotyl length of the germinated seeds, seedling and root lengths, No. leaves/seedling, fresh and dry weights of leaves and roots, as well as leaves content of chlorophyll $a, b$, carotenoids and total soluble sugars were only improved by soaking in tap water for $48 \mathrm{~h}$ treatment that recorded the highest averages compared to control in most cases of both seasons. The leaf content of total indoles was fluctuated in both seasons, while that of total phenols was markedly decreased only in the seedlings generated from the seeds soaked in tap water, especially for $48 \mathrm{~h}$., as this treatment generally gave the best equilibrium between total indoles and total phenols content in the two seasons.

Hence, it can be advised to soaking the seeds of Sausage tree in tap water for $48 \mathrm{~h}$. before sowing under the ambient conditions to get the best germination traits and highest quality of the seedlings.

Key words: Ornamental trees, Sausage trees (Kigelia pinnata), seed germination, pregermination treatments.

\section{INTRODUCTION}

The Sausage tree (Kigelia pinnata (Jacq) D.C. Syn. K. africana), a tree that belongs to Fam. Bignoniaceae, native to Tropical Africa, growing up to $20 \mathrm{~m}$ tall; the park is grey and smooth at first, peeling on older trees. The wood is pale brown or yellowish, undifferentiated and not prone to cracking (Roodt, 1992). It is evergreen where rainfall occurs throughout the year, but deciduous where there is a long dry season. The leaves are opposite or in whorls of 3, 30-50 $\mathrm{cm}$, pinnate with $6-10$ oral leaflets up to 20 $\mathrm{cm}$ long. The terminal leaflet can be either present or absent. The flowers (and later the fruits) hang down from branches on long flexible stems (2-6m long). Their scent is most notable at night. The fruit is woody berry from $30-100 \mathrm{~cm}$ long and up to $18 \mathrm{~cm}$ broad, it weights between $5-10 \mathrm{~kg}$ and hangs down on long, rope-like peduncles. Its pulp is fibrous and contains numerous seeds, it is eaten by several species of mammals (Huxley, 1992). 


\section{Studies on seed germination of sausage tree (Kigelia pinnata (Jacq) D.C.)}

This tree is widely grown as an ornamental tree in tropical regions for its decorative flowers and unusual fruits. The fruit is believed to be a cure for a wide range of ailments, from rheumatism to syphilis and snake bites. An alcoholic peverage similar to beer is also made from it. The fresh fruits are prepared for consumption by drying, roasting or fermentation (Roodt, 1992).

The tree is mainly propagated from fresh seeds or from truncheons, seeds usually germinate through 25-30 days because they are parasitized in the velds by insects that make small holes in the exocarps, and that accelerates germination although the seeds are viable for one season only (Site1, 2012). However, information in the literature about seeds germination of Sausage tree are very limited, while several reports are available for other trees. In this regard, Scalon et al., (2008) found that soaking the seeds of Pyrostegia venusta (Bignoniaceae) in tap water for $24 \mathrm{~h}$ led to higher germination percentage and velocity and higher seedling fresh and dry matter. Likewise, Trivedi and Joshi (2014) recorded that fresh seeds of Stereospermum suaveolens (Bignoniaceae) pre-soaked overnight in distilled water showed maximum percent of germination and higher seedling growth.

Similar observations were also revealed by Agba et al., (2005) on Mucuna flagellipes, Uniyal et al., (2007) on Dalbergia sissoo, Negi and Madwal (2008) on Bauhinia variegata, Grewia disperma, Schleichera oleosa and Terminalia bellirica, Merou et al., (2011) on Albizia julibrissin, Azad et al., (2013) on Tamarindus indica, Shahin et al., (2015) on Calliandra haematocephala and Shahin et al., (2015) whom declared that soaking seeds of Dillenia indica in tap water for $72 \mathrm{~h}$ greatly improved germination percentage and velocity, mean germination rate, germination rate index, vigour index, seeds viability, plumule length, growth and dry matter of the generated seedlings, as well as leaf content of pigments, total soluble sugars and indoles.
However, the purpose of this work is to find out the best suitable pre-sowing treatment for enhancing and accelerating germination of Sausage tree seeds plus improving growth and quality of the new formed seedlings.

\section{MATERIALS AND METHODS}

The current work was carried out under the full sun at the nursery of Orman Botanic Garden, Hort. Res. Inst., ARC, Giza, Egypt throughout the two successive seasons of 2014 and 2015 to study the response of Sausage tree seeds to some pre-sowing ordinary treatments.

Thus, the woody berry fruits of Sausage tree (Kigelia pinnata (Jacq) D.C.) were obtained from Giza Zoo on tenth of March for each season and fermented in stagnant water till the fibrous pulp rot and soften, then the seeds were gently get out, washed in running water and dried in the shade for 1 day. On the first of May in each season, the dried seeds (the mean weight of 10 seeds ranged between 1.12-1.16 g) were sterilized with sodium hydrochloride solution (10 \%) for 10 minutes, next rinsed several times with sterile distilled water, then subjected to the following pre-sowing treatments.

1. Seeds without treatment (control).

2. Soaking in tap water for either 24 or 48 hours under ambient air conditions.

3. Soaking in hot water $\left(60-70{ }^{\circ} \mathrm{C}\right)$ for 24 hours.

4. Soaking in diluted sulphuric acid (50\%) for either 1 or 2 hours, followed by soaking in tap water for 12 hours under ambient air conditions.

The treated seeds and those of control were sown directly after treatment in $16-\mathrm{cm}-$ diameter plastic pots filled with about $1.5 \mathrm{~kg}$ of sand and Al-Obour compost mixture (2 : 1 , by volume). The physical and chemical analyses of the sand and Al-Obour compost used in the two seasons are shown in Tables (1) and (2), respectively. 
Table (1): The physical and chemical analyses of the sand used in both seasons.

\begin{tabular}{|c|c|c|c|c|c|c|c|c|c|c|c|c|c|}
\hline \multicolumn{4}{|c|}{$\begin{array}{l}\text { Particle size distribution } \\
(\%)\end{array}$} & \multirow{2}{*}{ S.P. } & \multirow{2}{*}{$\begin{array}{l}\text { E.C. } \\
(\mathrm{dS} / \mathrm{m})\end{array}$} & \multirow[b]{2}{*}{$\mathrm{pH}$} & \multicolumn{4}{|c|}{ Cations (meq/l) } & \multicolumn{3}{|c|}{ Anions (Meq/l) } \\
\hline $\begin{array}{c}\text { Coarse } \\
\text { sand }\end{array}$ & $\begin{array}{l}\text { Fine } \\
\text { sand }\end{array}$ & Silt & Clay & & & & $\mathrm{Ca}^{++}$ & $\mathrm{Mg}^{++}$ & $\mathrm{Na}^{+}$ & $\mathrm{K}^{+}$ & $\mathrm{HCO}_{3}$ & $\mathrm{Cl}^{-}$ & $\mathrm{SO}_{4}^{--}$ \\
\hline 79.83 & 9.58 & 3.53 & 7.06 & 22.46 & 3.50 & 7.78 & 13.46 & 4.98 & 20.41 & 0.63 & 3.58 & 17.96 & 17.94 \\
\hline
\end{tabular}

Table (2): The physical and chemical analyses of compost Al-Obour used in the two seasons.

\begin{tabular}{|c|c|c|c|c|c|}
\hline Character & Content & Character & Content & Character & Content \\
\hline Weight of $/ \mathrm{m}^{3}(\mathrm{~kg})$ & $500-550$ & Organic matter $(\%)$ & $34-38$ & $\mathrm{Fe}(\mathrm{ppm})$ & $1500-1800$ \\
\hline Humidity $(\%)$ & $25-30$ & Organic carbon $(\%)$ & $19.8-22$ & $\mathrm{Mn}(\mathrm{ppm})$ & $25-50$ \\
\hline $\mathrm{pH}(1-2.5)$ & $7.5-8.0$ & $\mathrm{C} / \mathrm{N} \mathrm{ratio}$ & $1-14.2$ & $\mathrm{Cu}(\mathrm{ppm})$ & $50-75$ \\
\hline Ec $\left(\mathrm{mmhos} / \mathrm{cm}^{2}\right)$ & $3-3.5$ & $\mathrm{NaCl}(\%)$ & $1.1-1.25$ & $\mathrm{Zn}(\mathrm{ppm})$ & $150-225$ \\
\hline Water hold capacity $(\%)$ & $250-300$ & Total P $(\%)$ & $0.5-0.75$ & Weed seeds & 00.00 \\
\hline Total N $(\%)$ & $1-1.4$ & Total K $(\%)$ & $1.25-1.75$ & Nematoda & 00.00 \\
\hline
\end{tabular}

- The used compost manufactured from plant residues and free from heavy metals and pollution. Analyses were done by: Producer Company.

A completely randomized design was used in the two seasons with three replicates as each pot contained 10 seeds stands for one replicate (Mead et al., 1993). Clearly visible hypocotyls protrusion was used as a criterion for germination. All agricultural practices needed for seeds care were carried out on the proper time. Number of germinated seeds was daily counted. At the end of each season (on June, $30^{\text {th }}$ ), data were recorded as follows:

\section{Germination characteristics:-}

1) Germination percentage ( $G \%$ ) from the following equation:

G. $\%=$ No. germinated seeds $/$ Total No. sown seeds $\times 100$

2) Germination velocity (G.V.) in days, which equal average number of days from sowing till emergence of the final hypovotyl.

3) Mean germination rate (MGR) in days = mean number of days till $50 \%$ germination (Odetola, 1987).

4) Germination rate index (GRI), which calculated from Bartled equation indicated by Hartmann and Kester
(1983). GRI $=A+(A+B)+(A+B+C)$ $+\ldots / N(A+B+C \ldots .$.$) .$

- Where: $A, B, C, \ldots$ etc. are number of germinated seeds counted at different times, and $\mathrm{N}$ is number of times at which the germinated seeds were counted.

5) Vigour index $(\mathrm{VI})=\mathrm{G} \% \mathrm{x}$ mean length of hypovotyl (Selvaraju and Selvaraj, 1994)

6) Seed viability (SV) = number of survived seedlings in each treatment after excluding the deteriorated and dead ones (Odetola, 1987).

7) Hypocotyl length of the germinated seeds (cm).

\section{Seedling growth characters:-}

Samples from the produced seedlings under the different used treatments were gently lifted to measure: seedling length $(\mathrm{cm})$, number of leaves/seedling, root length $(\mathrm{cm})$ and leaves and roots fresh and dry weights $(\mathrm{g})$.

\section{Chemical determinations:-}

In fresh leaf samples, the photosynthetic pigments (chlorophyll a, b and carotenoids, $\mathrm{mg} / \mathrm{g}$. f.w.), the percent of total soluble sugars, as well as total indoles and total 
phenols (mg/100 g f.w.) were measured according to the methods described by Yadava (1986), Dubois et al., (1966), A.O.A.C (1990) and William et al., (1965), respectively.

Data were then tabulated and statistically analyzed using SAS (2009) program, which was followed by Duncan's New Multiple Range Test (Steel and Torrie, 1980) to verify the significancy between the means of various treatments.

\section{RESULTS AND DISCUSSION Effect of pre-germination treatments on: \\ 1- Germination characteristics:}

It is obvious from data averaged in Table

(3) that the maximal percent of germination (100\%) was achieved in the two seasons by soaking the seeds in tap water for $48 \mathrm{~h}$ treatment and was followed by soaking in tap water for $24 \mathrm{~h}$ treatment, which raised the mean of this parameter to $80 \%$ with significant differences compared to control treatment that gave $65.83 \%$ germination in the first season and $67.33 \%$ in the second one. This may indicate the ability of the seeds to absorb tap water well, especially when they immersed in it for longer period, and that of course activates hydrolysis enzymes which decompose the complex food reserves to simple sugars supply the embryo with energy necessary for its growth (Agba, et al., 2005). In this regard, Uniyal et al., (2007) noticed that soaking of Dalbergia sissoo seeds in tap water for $24 \mathrm{~h}$. favoured germination up to $96.84 \%$ against $68.42 \%$ for control.

On the other side, the least percent of germination was attained in both seasons by soaking either in hot water for $24 \mathrm{~h}$ or in diluted sulphuric acid (50\%) for 1 or 2 h., as these 3 treatments reduced germination \% to $50.47,50.00$ and $41.67 \%$ in the first season and to $52.50,50.16$ and $40.83 \%$ in the second one compared to control (Photo, $1)$.
This may be attributed to subjecting the embryo to deterioration by either sulphuric acid or hot water. In this concern, Chikumba et al., (2006) stated that the 10-min sulphuric acid treatment increased germination of Macrotyloma daltonii seeds from 21 to $38 \%$, but 20-min treatment reduced germination and increased the number of dead seeds. Souza et al., (2012) found that after treatment of Cassia tora seeds with hot water, the lens detached from the coat, and that prevented the water from contacting the lens inhibited water absorption in hot-water-treated seeds. Thus, hot water had no effect on seed germination. This result was emphasized by Pant and Chauhan (2013) who revealed that hot water treatment increased germination \% of $C$. tora seeds at $50{ }^{\circ} \mathrm{C}(44.54 \%)$, while further increase in temperature drastically reduced the germination. Likewise, Kavita and Kumar (2014), reported that seeds of Stylosanthes guianensis cv. Cook treated with hot water showed maximum death compared to other treatments.

The least number of days passed to score either $100 \%$ germination (G.V.) or 50 $\%$ germination (MGR) was also recorded by soaking in tap water treatment for $48 \mathrm{~h}$ was and followed directly by soaking treatment for only $24 \mathrm{~h}$. On the contrary, soaking the seeds in either hot water or diluted $\mathrm{H}_{2} \mathrm{SO}_{4}$ significantly elongated these two parameters relative to control in most cases of both seasons. The mean of germination rate index (GRI) was slightly increased over control by the accomplished treatments with few exceptions in the two seasons, while the means of vigour index (VI), seed viability (S.V.) and hypocotyl length of the germinated seeds $(\mathrm{cm})$ were improved only by soaking treatments in tap water, especially for $48 \mathrm{~h}$ one which gave the highest records in the two seasons. This may be ascribed to that prolonging soaking time to $48 \mathrm{~h}$. gave a chance for tap water to penetrate the hard seeds in amount sufficient to activate germination more than the other treatments. 
Table (3): Effect of pregermination treatments on germination traits of Kigelia pinnata (Jacq.) D.C. tree seeds during 2014 and 2015 seasons.

\begin{tabular}{|c|c|c|c|c|c|c|c|}
\hline Pre-germination treatments & $\begin{array}{c}\text { Germination } \\
\text { percentage } \\
\text { (G. \%) }\end{array}$ & $\begin{array}{c}\text { Germination } \\
\text { velocity } \\
\text { (G.V., day) }\end{array}$ & $\begin{array}{c}\text { Mean } \\
\text { germination } \\
\text { rate } \\
\text { (MGR, day) } \\
\end{array}$ & $\begin{array}{c}\text { Germination } \\
\text { rate index } \\
(\mathrm{GRI})\end{array}$ & $\mid \begin{array}{c}\text { Vigour } \\
\text { index } \\
(\mathrm{VI})\end{array}$ & $\begin{array}{c}\text { Seed } \\
\text { viability } \\
\text { (S.V.) }\end{array}$ & $\begin{array}{c}\text { Hypocotyl } \\
\text { length } \\
\text { (cm) }\end{array}$ \\
\hline \multicolumn{8}{|c|}{ First season: 2014} \\
\hline Control & $65.83 c$ & $30.14 b$ & $27.21 b$ & $0.57 a$ & $5.00 \mathrm{c}$ & $67.81 \mathrm{c}$ & $1.03 b$ \\
\hline Soaking in tap water (24 h.) & $80.00 b$ & $27.57 \mathrm{c}$ & $23.20 c$ & $0.56 a$ & $7.33 b$ & $88.00 \mathrm{~b}$ & $1.10 \mathrm{~b}$ \\
\hline Soaking in tap water (48 h.) & $100.00 a$ & $25.30 d$ & $14.40 d$ & $0.60 a$ & $10.00 a$ & $133.00 \mathrm{a}$ & $1.33 a$ \\
\hline Soaking in hot water (24 h) & $50.47 d$ & $32.25 a$ & $32.25 a$ & $0.60 a$ & $3.10 \mathrm{~d}$ & $41.89 d$ & $0.83 c$ \\
\hline $\begin{array}{l}\text { Soaking in diluted } \mathrm{H}_{2} \mathrm{SO}_{4}(1 \mathrm{~h} .)+ \\
\text { soaking in tap water }(12 \text { h.) }\end{array}$ & $50.00 d$ & $30.63 b$ & $30.63 a$ & $0.60 a$ & $3.18 d$ & $35.50 \mathrm{~d}$ & $0.71 d$ \\
\hline $\begin{array}{l}\text { Soaking in diluted } \mathrm{H}_{2} \mathrm{SO}_{4}(2 \mathrm{~h} .)+ \\
\text { soaking in tap water }(12 \mathrm{~h} .)\end{array}$ & $1.67 e$ & $33.25 a$ & - & $0.63 a$ & $2.50 \mathrm{~d}$ & $37.50 \mathrm{~d}$ & $0.90 c$ \\
\hline \multicolumn{8}{|c|}{ Second season: 2015} \\
\hline Control & $67.33 c$ & $31.28 \mathrm{bc}$ & $28.00 \mathrm{~b}$ & $0.57 a$ & $4.67 \mathrm{c}$ & $67.33 \mathrm{c}$ & $1.00 \mathrm{bc}$ \\
\hline Soaking in tap water (24 h.) & $80.00 \mathrm{~b}$ & $29.56 c$ & $24.79 c$ & $0.58 a$ & $7.00 \mathrm{~b}$ & $89.60 \mathrm{~b}$ & $1.12 b$ \\
\hline Soaking in tap water (48 h.) & $100.00 a$ & $26.00 \mathrm{~d}$ & $15.08 d$ & $0.60 a$ & $10.00 a$ & $131.00 \mathrm{a}$ & $1.31 \mathrm{a}$ \\
\hline Soaking in hot water (24 h) & $52.50 \mathrm{~d}$ & $34.60 a$ & $34.50 \mathrm{a}$ & $0.61 a$ & $3.00 \mathrm{~d}$ & $44.63 d$ & $0.85 c$ \\
\hline $\begin{array}{l}\text { Soaking in diluted } \mathrm{H}_{2} \mathrm{SO}_{4}(1 \text { h. })+ \\
\text { soaking in tap water }(12 \text { h. })\end{array}$ & $50.16 d$ & $32.78 b$ & $32.71 \mathrm{a}$ & $0.61 \mathrm{a}$ & $3.00 \mathrm{~d}$ & $35.11 \mathrm{de}$ & $0.70 d$ \\
\hline $\begin{array}{l}\text { Soaking in diluted } \mathrm{H}_{2} \mathrm{SO}_{4}(2 \mathrm{~h} \text {. })+ \\
\text { soaking in tap water }(12 \text { h.) }\end{array}$ & $40.83 e$ & $35.67 a$ & - & $0.63 a$ & $2.50 \mathrm{~d}$ & $34.30 \mathrm{e}$ & $0.84 c$ \\
\hline
\end{tabular}

- Means within a column having the same letters are not significantly different according to Duncan's New Multiple Range Test at $5 \%$ level.

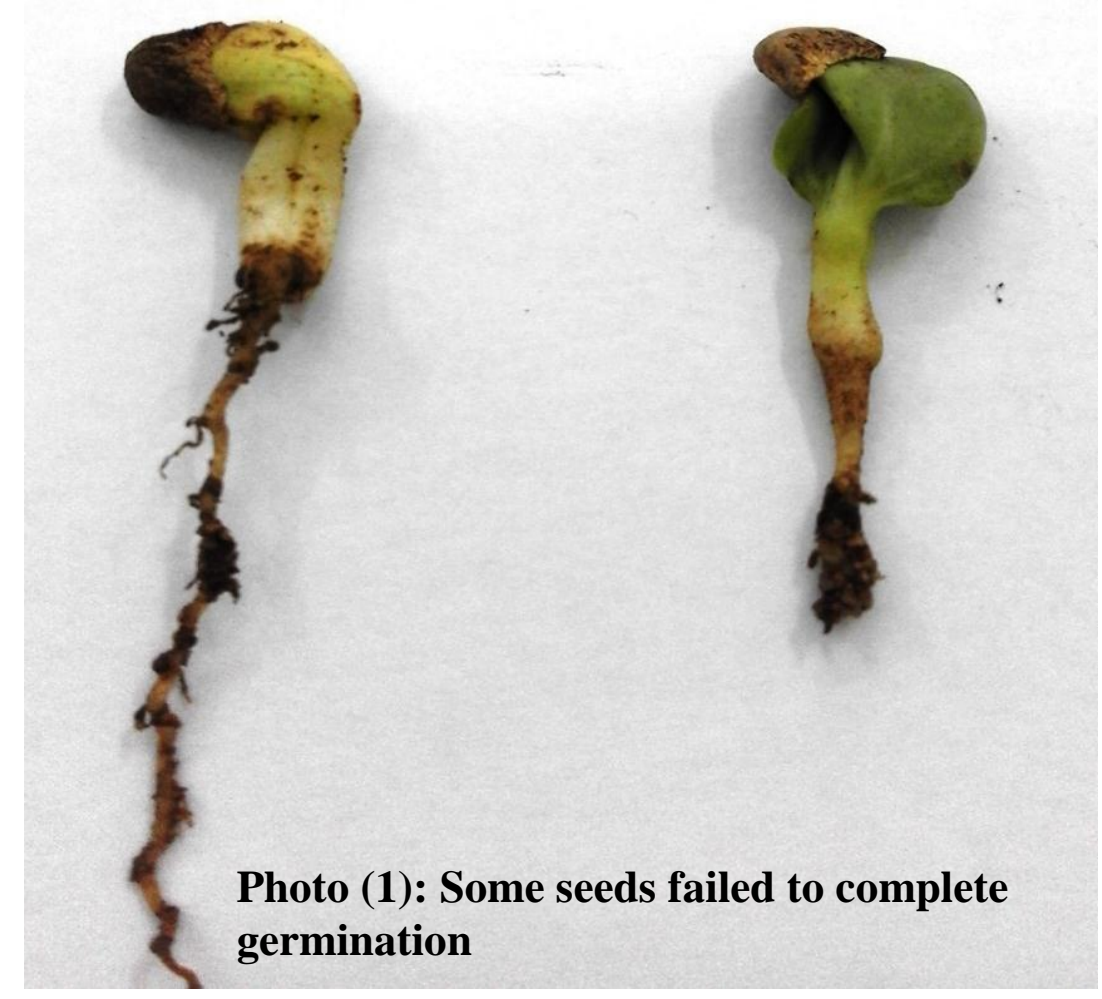


The present findings conform with previous ones mentioned by Scalon et al., (2008) on Pyrostegia venusta and Agba et al., (2005) whom postulated that soaking Mucuna flagellipes seeds in water at room temperature for 36-48 $\mathrm{h}$ resulted in significantly higher cumulative germination over planting of seeds without pre-soaking. On seeds of Bauhinia variegata, Grewia disperma, Schleichera oleosa and Terminalia bellirica, Negi and Madwal (2008) claimed that the highest germination \% was observed when the seeds were soaked in cold water under normal temperature up to $24 \mathrm{~h}$ followed by soaking in hot water up to $12 \mathrm{~h}>$ soaking in hot water up to $24 \mathrm{~h}>$ soaking in diluted $\mathrm{H}_{2} \mathrm{SO}_{4}$ up to $10 \mathrm{~min}$., and that depend upon the nature of seed coat.

\section{2- Seedling growth parameters:}

Similarly, were those results of vegetative and root growth traits of the seedlings resulted from the germinated seeds (Table, 4), as the means of seedling and root lengths $(\mathrm{cm})$, number of the leaves/seedling and the leaves and roots fresh and dry weights (g) were markedly improved by soaking in tap water treatment for either 24 or $48 \mathrm{~h}$ comparing with control treatment, but were decreased by soaking in either hot water or diluted sulphuric acid for any time. However, the superiority in all previous characters was also found due to soaking in tap water for $48 \mathrm{~h}$., which gave the longest length of seedling and root, higher No. of leaves and the heaviest fresh and dry weights of leaves and roots over the control and all other treatments, (Photo, 2) but the inferiority was ascribed to soaking in diluted $\mathrm{H}_{2} \mathrm{SO}_{4}$ for $2 \mathrm{~h}+$ soaking in tap water for $12 \mathrm{~h}$ treatment which recorded the least means at all.

Table (4): Effect of pregermination treatments on growth traits of Kigelia pinnata (Jacq.) D.C. seedlings during 2014 and 2015 seasons.

\begin{tabular}{|c|c|c|c|c|c|c|c|}
\hline \multirow{2}{*}{ Pre-germination treatments } & \multirow{2}{*}{$\begin{array}{c}\text { Seedling } \\
\text { length } \\
(\mathrm{cm})\end{array}$} & \multirow{2}{*}{\begin{tabular}{|c|} 
No. \\
leaves \\
per \\
seedling
\end{tabular}} & \multirow{2}{*}{$\begin{array}{c}\text { Root } \\
\text { length } \\
\text { (cm.) }\end{array}$} & \multicolumn{2}{|c|}{ Leaves } & \multicolumn{2}{|c|}{ Roots } \\
\hline & & & & F.W. (g) & D.W. (g) & F.W.(g) & D.W.(g) \\
\hline \multicolumn{8}{|c|}{ First season: 2014} \\
\hline Control & $6.87 \mathrm{~b}$ & $3.67 \mathrm{~b}$ & $5.10 \mathrm{~b}$ & $0.811 \mathrm{c}$ & $0.101 \mathrm{~b}$ & $0.088 \mathrm{c}$ & $0.051 \mathrm{bc}$ \\
\hline Soaking in tap water (24 h.) & $8.90 \mathrm{ab}$ & $4.00 \mathrm{~b}$ & $6.21 \mathrm{a}$ & $0.989 \mathrm{~b}$ & $0.118 \mathrm{ab}$ & $0.123 b$ & $0.067 b$ \\
\hline Soaking in tap water (48 h.) & $1 a$ & $5.33 a$ & $6.80 \mathrm{a}$ & $1.215 \mathrm{a}$ & $0.137 a$ & $0.190 a$ & $0.089 a$ \\
\hline Soak & 5 & $3.31 b$ & & $0.742 d$ & $0.083 \mathrm{bc}$ & $0.091 \mathrm{c}$ & $0.046 \mathrm{bc}$ \\
\hline $\begin{array}{l}\text { Soaking in diluted } \mathrm{H}_{2} \mathrm{SO}_{4}(1 \mathrm{~h} .) \\
+ \text { soaking in tap water }(12 \mathrm{~h} \text {.) }\end{array}$ & $5.78 \mathrm{bc}$ & $3.40 \mathrm{~b}$ & $4.96 \mathrm{bc}$ & $0.637 \mathrm{e}$ & $0.071 \mathrm{c}$ & $0.079 \mathrm{~cd}$ & $0.044 \mathrm{bc}$ \\
\hline $\begin{array}{l}\text { Soaking in diluted } \mathrm{H}_{2} \mathrm{SO}_{4}(2 \mathrm{~h} \text {. }) \\
+ \text { soaking in tap water }(12 \text { h.) }\end{array}$ & Bc & $2.38 \mathrm{c}$ & $.87 \mathrm{c}$ & $0.533 f$ & $58 \mathrm{c}$ & $0.058 d$ & $0.031 \mathrm{c}$ \\
\hline \multicolumn{8}{|c|}{ Second season: 2015} \\
\hline Control & $7.03 b$ & $3.80 \mathrm{~b}$ & $5.20 \mathrm{~b}$ & $0.842 \mathrm{c}$ & $0.105 b$ & $0.090 c$ & $0.052 \mathrm{bc}$ \\
\hline Soaking in tap water (24 h.) & $9.13 a b$ & $4.21 b$ & $6.67 \mathrm{a}$ & $1.041 \mathrm{~b}$ & $0.126 \mathrm{ab}$ & $0.133 b$ & $0.073 b$ \\
\hline Soaking in tap water (48 h.) & $10.00 \mathrm{a}$ & $5.61 \mathrm{a}$ & $7.30 \mathrm{a}$ & $1.279 a$ & $0.145 a$ & $0.204 a$ & $0.097 a$ \\
\hline Soaki & $4 \mathrm{bc}$ & $3.38 \mathrm{~b}$ & & $0.758 d$ & 0.08 & $0.079 \mathrm{~cd}$ & $0.050 \mathrm{c}$ \\
\hline $\begin{array}{l}\text { Soaking in diluted } \mathrm{H}_{2} \mathrm{SO}_{4}(1 \mathrm{~h} \text {.) } \\
+ \text { soaking in tap water }(12 \mathrm{~h} \text {.) }\end{array}$ & $6.15 b c$ & $3.60 \mathrm{~b}$ & 00 & $0.676 \mathrm{e}$ & $0.076 \mathrm{c}$ & $0.071 \mathrm{c}$ & $0.041 \mathrm{c}$ \\
\hline $\begin{array}{l}\text { Soaking in diluted } \mathrm{H}_{2} \mathrm{SO}_{4}(2 \mathrm{~h} .) \\
+ \text { soaking in tap water }(12 \text { h. })\end{array}$ & $5.11 \mathrm{c}$ & $2.57 \mathrm{c}$ & $5 c$ & $0.583 f$ & $0.066 c$ & $0.076 c$ & $0.041 \mathrm{c}$ \\
\hline
\end{tabular}

- Means within a column having the same letters are not significantly different according to Duncan's New Multiple Range Test at $5 \%$ level. 

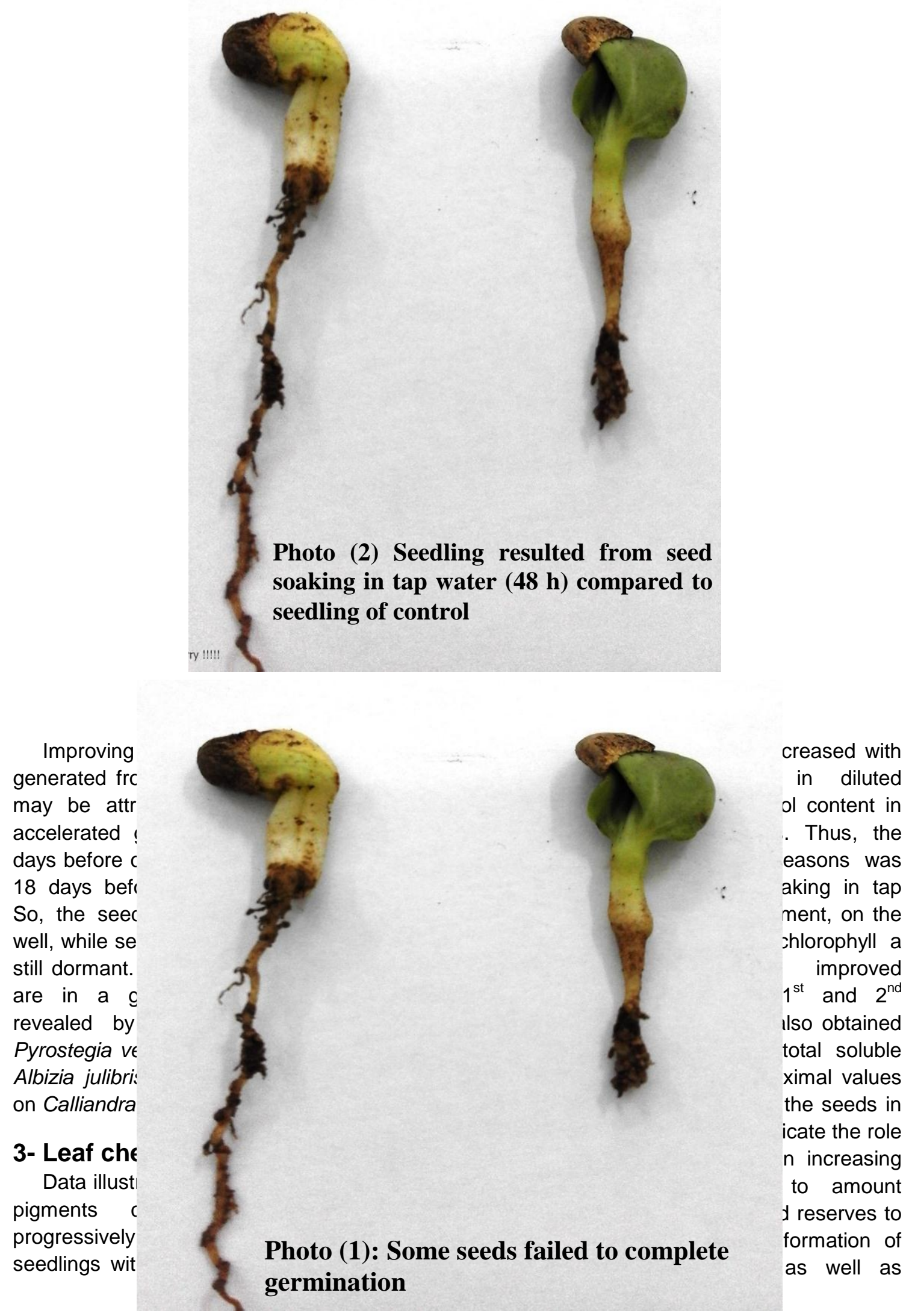


\section{Studies on seed germination of sausage tree (Kigelia pinnata (Jacq) D.C.)}

chlorophyll appearance during normal leaf growth (Agba et al., 2005).

Data also showed that total indoles content (mg/100 g f.w.) was fluctuated in the two seasons, whereas total phenols content (mg/100 g.f.w.) was greatly decreased by soaking in tap water, especially for $48 \mathrm{~h}$ period which decreased such constituent to the minimum values in both seasons. The opposite was the right concerning the effect of hot water and diluted $\mathrm{H}_{2} \mathrm{SO}_{4}$ treatments which raised total phenols content over control to more than 5- to 6- fold in the first season and to more than 3 -fold in the second one. In general, the best equilibrium between total indoles and total phenols was achieved in the two seasons by soaking the seeds in tap water for $48 \mathrm{~h}$ treatment as this treatment elevated content of total indoles to the highest values, but decreased total phenols to the minimal ones and this may be the main reason for obtaining the best germination characteristics and high quality of the produced seedlings.

On the same line, were those results explored by Azad et al., (2013) on Tamarindus indica and Shahin et al., (2015) whom detected that immersing seeds of Dillenia indica in tap water for $72 \mathrm{~h}$ caused a marked increment in contents of pigments, total soluble sugars and indoles in the leaves of new generated seedlings.

Hence, it is recommended to soak the Sausage tree seeds in tap water for 48 hours under ambient conditions for favouring germination and improving the seedling quality.

Table (5): Effect of pregermination treatments on chemical composition of Kigelia pinnata (Jacq.) D.C. seedlings leaves during 2014 and 2015 seasons.

\begin{tabular}{|c|c|c|c|c|c|c|c|c|c|c|c|c|}
\hline \multirow{3}{*}{ Pre-germination treatments } & \multicolumn{6}{|c|}{ Pigments content (mg/g. f.w.) } & \multirow{2}{*}{\multicolumn{2}{|c|}{$\begin{array}{c}\text { Total } \\
\text { soluble } \\
\text { sugars } \\
(\%)\end{array}$}} & \multirow{2}{*}{\multicolumn{2}{|c|}{$\begin{array}{c}\text { Total } \\
\text { indoles } \\
\text { (mg/100 g. } \\
\text { f.w.) }\end{array}$}} & \multirow{2}{*}{\multicolumn{2}{|c|}{$\begin{array}{c}\text { Total } \\
\text { phenols } \\
\text { (mg/100 g. } \\
\text { f.w.) }\end{array}$}} \\
\hline & \multicolumn{2}{|c|}{$\begin{array}{c}\text { Chlorophyll } \\
\text { (a) }\end{array}$} & \multicolumn{2}{|c|}{$\begin{array}{c}\text { Chlorophyll } \\
\text { (b) }\end{array}$} & \multicolumn{2}{|c|}{ Carotenoids } & & & & & & \\
\hline & 2014 & 2015 & 2014 & 2015 & 2014 & 2015 & 2014 & 2015 & 2014 & 2015 & 2014 & 2015 \\
\hline Control & 1.372 & 1.48 & $0.363 \mid$ & 0.389 & 0.197 & 0.206 & 3.085 & 3.138 & 1.014 & 1.311 & 2.045 & 2.19 \\
\hline Soaking in tap water (24 h.) & 1.524 & 1.646 & 0.365 & 0.396 & 0.256 & 0.247 & 3.170 & 3.332 & 1.428 & 1.261 & 0.789 & 0.912 \\
\hline Soaking in tap water (48 h.) & 1.945 & 2.101 & $0.631 \mid$ & 0.604 & 0.387 & 0.371 & 3.469 & 3.599 & 1.936 & 1.503 & 0.313 & 0.343 \\
\hline Soaking in hot water (24 h) & 1.359 & 1.471 & $0.343 \mid$ & 0.371 & 0.199 & 0.215 & 2.925 & 3.160 & 1.063 & 31.368 & 11.694 & 7.867 \\
\hline $\begin{array}{l}\text { Soaking in diluted } \mathrm{H}_{2} \mathrm{SO}_{4}(1 \mathrm{~h} \text {.) } \\
+ \text { soaking in tap water }(12 \mathrm{~h} \text {.) }\end{array}$ & 1.217 & 1.318 & 0.327 & 0.357 & 0.185 & 0.201 & 2.900 & 3.102 & 1.085 & 1.210 & 11.865 & 7.834 \\
\hline $\begin{array}{l}\text { Soaking in diluted } \mathrm{H}_{2} \mathrm{SO}_{4}(2 \mathrm{~h} \text {.) } \\
+ \text { soaking in tap water }(12 \mathrm{~h} \text {.) }\end{array}$ & 1.269 & 1.301 & 0.321 & 0.396 & 0.167 & 0.183 & 2.737 & 2.809 & 1.323 & 1.096 & 13.153 & 7.168 \\
\hline
\end{tabular}




\section{REFERENCES}

Agba, O. A., J. E. Asiegbu and C. Omaliko (2005). Effect of length of soaking in water at room temperature and hot water treatment on the germination of Mucuna flagellipes (Vogel ex Hook) seeds. Global J. Agric. Sci., 4 (1): 15-18.

A.O.A.C. Association of Official Agricultural Chemists (1990). "Official Methods of Analysis of the Association of Official Agricultural Chemists". $15^{\text {th }}$ Ed., Arlington, Virginia 22201: 877-878.

Azad, M. S., N. Nahar and M. A. Matin (2013). Effects of variation in seed sources and pre-sowing treatments on seed germination of Tamarindus indica: a multi-purpose tree species in Bengladesh. Forest Science and Practice, 15 (2): 121-129.

Chikumba, N., C. Mapiye and X. Poshiwa (2006). Breaking seed coat dormancy in Macrotyloma daltonii. Rangeland J., 28 (2): 179-182.

Dubois, M., F. Smith, K. A. Illes, J. K. Hamilton and P. A. Rebers (1966). Colorimetric mehod for determination of sugars and related substances. Ann. Chem., 28 (3): 350-356.

Hartmann, H.T. and Kester, D. E. (1983). Plant Propagation: Principles and Practices. Prentice-Hall Inc., Inglewood Cliffs, N. J., 662pp.

Huxley, A., ed (1992). New RHS Dictionary of Gardening, Macmillan Pub. Co., Vol. 2, $747 \mathrm{pp}$.

Kavita, S. R. and Kumar, V. (2014). Overcoming the hardseededness in Stylosanthes guianensis cv. Cook. Karnataka J. Agric. Sci., 27 (2): 135-138.

Mead, R., R. N. Curnow and A. M. Harted (1993). Statistical Methods in Agriculture and Experimental Biology. $2^{\text {nd }}$ Ed., Chapman \& Hall Ltd., London, 335 pp.

Merou, T., I. Takos, E. Konstantinidou, S. Galatsidas and G. Varsamis (2011). Effect of pretreatment methods on germination of Albizia julibrissin seeds. Seed Sci. and Techno., 39 (1): 248-252.
Negi, K. S. and K. Madwal (2008). Impact of pre-sowing seed treatments on germination of common fodder tree species of lower Siwalik range of Garhwal Himalayas. Indian J. Forestry, 31 (1): 73-75.

Odetola, J. A. (1987). Studies on seed dormancy, viability and germination in ornamental palms. Principles, 31 (1): 2430.

Pant, G. and U. K. Chauhan (2013). Germination behaviour of Cassia tora seeds in various pre-sowing treatment methods. Inter. J. of Pharma and BioSci., 4 (3): 773-778.

Roodt, V. (1992). Kigelia african in: The Shell Field Guide to the Common Trees of the Okavango Delta \& Moremi Game Reserve, Botswana.

SAS, Institute. (2009). SAS/STAT, User's Guides: Statistics. Vers. 9, SAS. Institute Inc. Cary, N.C., USA.

Scalon, S.P., M. C. Vieira, A.A. Lima, C. M. Souza and R. M. Mussury (2008). Pregerminatve treatments and incubation temperatures on the germination of Cipode-Sao-Joao (Pyrostegia venusta (Ker Gawl) Miers)- Bignoniaceae. Revista Brasileira de Plantas Medicinais, 10 (4): 37-42.

Selvaraju, P. and J. A. Selvaraj (1994). Effect of pre-sowing treatments on germination and vigour of seed in marigold (Tagetes erecta L.). Madras Agric. J., 81 (9): 469-497.

Shahin, S.M., Amal S. El-Fouly and Azza M. Abdel-Moniem (2015). Seeds of Elephant apple (Dillenia indica L.) response to some pre-germination treatments. The $1^{\text {st }}$ Conf. of SSFOP "Future of Ornam. Plants in Egypt", Feb. $22^{\text {nd }}$,Cairo, Scie. J. Flowers \& Ornam. Plants 2 (1): 39-50.

Shahin, S.M., A. S. Tawila and Reem M. Said (2015). Effect of pre-sowing treatments on seed germination and seedling growth of Calliandra haematocephala Hassk. shrub. The $1^{\text {st }}$ Conf. of SSFOP (Future of Ornamental Plants in Egypt), Cairo, 22 ${ }^{\text {nd }}$ Feb., 
Scientific J. Flowers \& Ornamental Plants, 2 (1): 11-21

Site, 1 (2012). "Germinating and growing common African indigenous tree" Sausage tree (Kigelia africana). http://www. Jacanaent. com/ Library/Trees/Sausage tree.htm.

Souza, T. V., C. H. Voltolini, M. Santos and M.T. Paulilo (2012). Water absorption and dormancy-braeaking requirements of physically dormant seeds of Schizolobium parahyba (Fabaceae Caesalpiniodeae). Seed Sci. Res., 22 (3): 169-176.

Steel, R. G. D. and J. H. Torrie (1980). Principles and procedures of statistics. McGrow Hill Book Co., Inc., New York, P: 377-400.
Trivedi, D. R. and A. G. Joshi (2014). Studies on seed germination of Stereospermum suaveolens with respect to different parameters. Environ. and Experim. Biology, 12 (1): 33-37.

Uniyal, A. K., B. Singh and C. S. Dhanai (2007). Effects of pretreatment on Dalbergia sissoo seed germination. Progressive Research, 2 (1/2): 144-146.

William, M., P. Chichlilo, P. A. Clifford and M. Reynolds (1965). Official Methods of Analysis of the Association of Official Agriculture Chemists, $10^{\text {th }}$ Ed., Washington D.C. 20044: 52-55.

Yadava, Y. L. (1986). Rapid and nondestructive methods to determine chlorophyll in intact leaves. HortScience, 21: 1449-1450. 


\section{دراسات على إنبات بذور المشطورة (شجرة السجق أو أم النجف)}

\section{ماجدة عبد الحميد أحمد}

قسم بحوث الحدائق النباتية، معهد بحوث البساتين، مركز البحوث الزراعية، الجيزة، مصر .

\section{الملخص العربى}

أجريت هذه الدراسة تحت الثمس الساطعة بمشتل حديقة الأورمان النباتية، معهد بحوث البساتين، الجيزة، مصر

خلال موسمي 2014، 2015 للتعرف على استجابة بذور شجرة السجق الصلبة ( Kigelia pinnata (Jacq) لبعض معاملات ما قبل الإنبات والتى اشتملت على: بذور غير معاملة (مقارنة)، النقع في ماء الصنبور

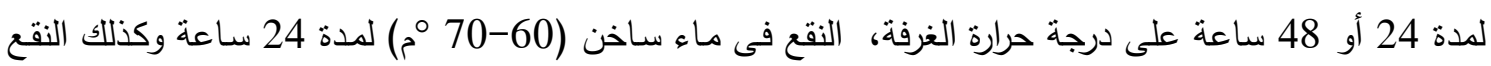

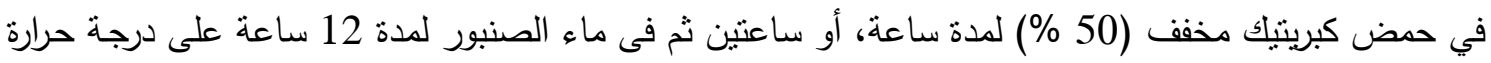

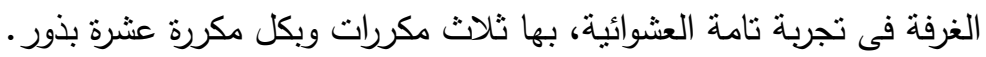

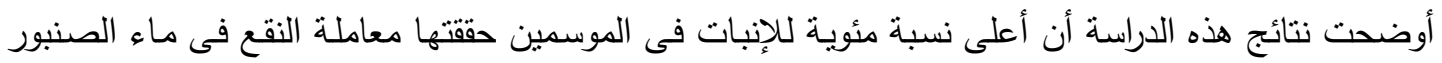

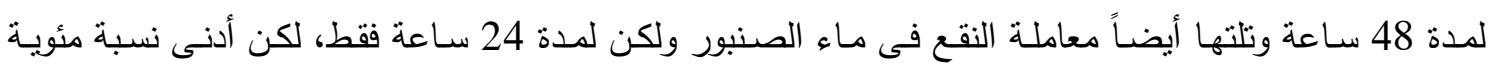

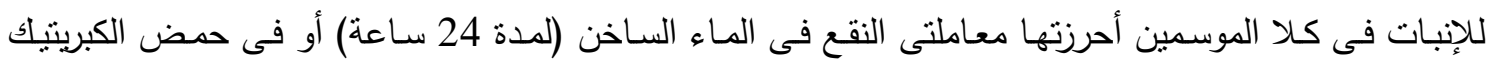

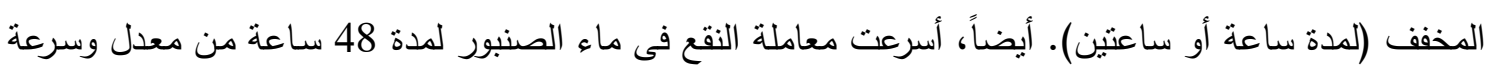

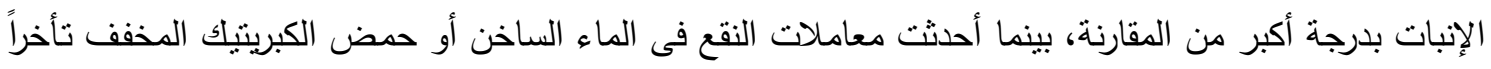
معنوياً فى هاتين الصفتين. ولقد حسنت معظم المعاملات المستخدمة بهذه الدراسة من منوسط دليل معدل الإنبات

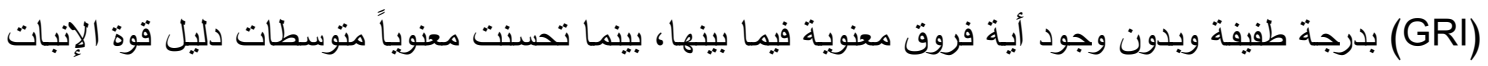

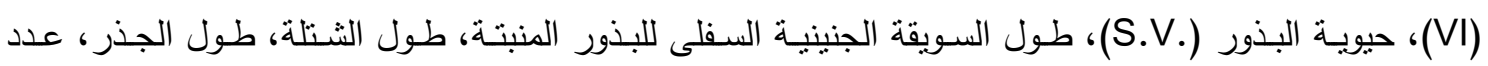
الأوراق/شتلة، الوزن الطازج والجاف للأوراق والجذور وكذلك محتوى الأوراق من كلوروفيللي أ، ب، الكاروتينويدات والسكريات الكلية الذائبة فقط بمعاملة النقع فى ماء الصنبور (48 ساعة) والتى سجلت أعلى المتوسطات مقارنة

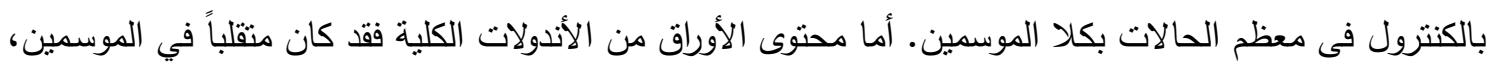

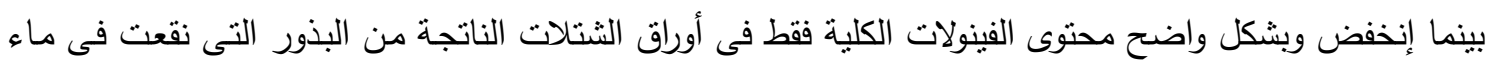
الصنبور ، وبصفة خاصة لمدة 48 ساعة، حيث أعطت هذه المعاملة بشكل عام أفضل توازن بين محتوى الأندولات الكلية والفينولات الكلية فى كلا موسمي الدراسة. وعليه، يمكن النصح بنقع بذور شجرة السجق (المشطورة) قبل الزراعة فى ماء الصنبور لمدة 48 ساعة على درجة حرارة الغرفة للحصول على أفضل صفات للإنبات وأعلى جودة للثتلات الناتجة. 
